Ryan, F. J. (1959). J. gen. Microbiol. 21, 530-549

\title{
Bacterial Mutation in a Stationary Phase and the Question of Cell Turnover
}

\author{
By F. J. RYAN \\ Department of Zoology, Columbia University, New York, U.S.A.
}

SUMMARY: During a stationary phase induced and maintained by the exhaustion of histidine, the total number of histidineless Escherichia coli $(\mathrm{h}-)$ remains constant as does the cytological appearance of the cells. If glucose is available to the starved bacteria they die at a rate of $c .10^{-2}$ per $\mathrm{hr}$., while mutations to a histidine-independent $(\mathrm{h}+)$ condition occur at a rate of $c .10^{-8}$ per bacterium per $\mathrm{hr}$. Bacteria adapted to use lactose behave essentially the same way when it, instead of glucose, is available during starvation; but if the starved cells are not fully adapted, death does not occur or is very slow (c. $10^{-3}$ per hr.) and the rate of mutation is $c .10^{-10}$. When no carbon source is available to the starved cells, mutations cannot be detected.

The following predictions served as tests of the hypothesis of cell-turnover, wherein some bacteria lyse only to be replaced at the same rate by the growth of othersthe mutations are presumed to have occurred during this cryptic growth:

(1) Mixtures of $\mathrm{h}^{-} \mathrm{lac}^{+}$and $\mathrm{h}^{-}$lac- bacteria in lactose medium where the $\mathrm{h}^{-} \mathrm{lac}^{+}$ has a selective advantage should show population shifts if cryptic growth were occurring.

(2) During the hypothesized lysis and growth the enzyme $\beta$-galactosidase should, at predictable rates, be lost to the medium from adapted cultures in the absence of lactose and developed in unadapted cultures in its presence.

(3) Penicillin should kill those cells that grow to replace others, causing an accelerated death and preventing the mutations from taking place.

(4) The lysis and death might be microscopically observable on an agar surface.

The hypothesis of turnover did not withstand any of these tests. It was concluded, therefore, that the bacteria under investigation were not dividing and that mutations - genotypic changes (Ryan, $1955 a$ ) -were taking place among them.

Reasons are given to suppose that the mutations result from errors in the replication of genetic material which is in the process of turnover within the non-dividing cells.

The stationary phase has been defined as that period, following exponential growth, when there is no further increase in the mass of a bacterial culture (Monod, 1949). It is often equated with the period beginning when the number of viable bacteria determined by plating ceases to increase. In enriched media such as nutrient broth a constant level of viable cells may be retained during a period in which the mass of the culture gradually increases, the cell death rate being approximately equal to the rate of production of new cells. In chemically defined media, on the other hand, the exhaustion of sugar may cause the cessation of growth; increase in cell mass, determined as optical density, and increase in viable cell number, may cease simultaneously. During such a stationary phase there may occur a progressive decrease in viable cell number without any measurable decrease in total cell mass or number.

A similar stationary phase, in which increase in both total and viable cell number stops at the same time, is found in chemically defined media when 
auxotrophic bacteria are limited in their growth by the exhaustion of the growth factor they require. All other nutrients in the medium may remain in excess, at least for some time, as is shown by the fact that growth factor independent mutants will overgrow such stationary cultures of auxotrophs when they occur among the latter. This fact has been utilized to measure the rate of mutation from auxotrophy to prototrophy in Escherichia coli (Ryan, $1955 a$ ).

Mutants which require histidine $\left(\mathrm{h}^{-}\right)$can be grown in a chemically defined medium with a limiting concentration of that amino acid. After the beginning of the stationary phase, those $\mathrm{h}^{+}$mutants present in some of a large number of cultures continue to grow because they do not require histidine, which has been completely consumed. If the $\mathrm{h}^{-}$population is limited at a proper level, those cultures containing $\mathrm{h}^{+}$mutants can be recognized by the resultant turbidity. From the frequency of cultures without any $h^{+}$mutants and the use of the zero term of the Poisson equation

$$
\boldsymbol{P}_{(0)}=e^{-m}
$$

the mean number of mutations/culture $(m)$ can be calculated. With $m$ and the average number of $\mathrm{h}^{-}$bacteria/culture $(N)$, the mutation rate/bacterium/ generation $(a)$ can be calculated according to the formula

$$
a=\frac{m \ln 2}{N}
$$

A maximum estimate of the time required for single $\mathrm{h}+$ mutants to overgrow $h^{-}$cultures, during whose growth they arise, can be made by the artificial introduction of single $\mathrm{h}^{+}$bacteria, marked, in this case, by an inability to use lactose (lac-). It was found that even several weeks after $h^{+}$mutants arising during the growth of $\mathrm{h}^{-}$populations should have overgrown (c. $50 \mathrm{hr}$.), new cultures adapted and became turbid. The rate of appearance of these late adaptive overgrowths was constant with time, and it could be shown that they resulted from new genotypic changes arising during the stationary phase. Phenotypic delay and the slow growth or delayed onset of division of some mutants arising during growth were eliminated as explanations (Ryan, 1955 a). It was therefore necessary to know whether the bacteria in the stationary phase actually were in a condition in which they did not divide or whether the population was in a dynamic state of cell turnover, some bacteria lysing and yielding histidine to other viable bacteria which grew and replaced them. It could be calculated from the facts that the mutation rate $(a)$ during growth was $c .3 \times 10^{-8} /$ bacterium/generation, while that during the stationary phase $(\mu)$ was $c .1 \times 10^{-9} /$ bacterium $/ \mathrm{hr}$., that about $2 \%$ of the $\mathrm{h}^{-}$population would have to turn over per hr. in order for the mutations observed to have occurred during a cryptic growth (Ryan, 1955a).

It is the purpose of the present communication to describe evidence; derived from a study of such a stationary phase, which indicates that the bacteria do not grow and divide; there does not seem to be any turnover of cells which could account for the mutations observed. 


\section{METHODS}

The stocks of Escherichia coli and the media employed have for the most part been described previously (Ryan \& Schneider, 1949a). The basal medium will here be referred to as $\mathbf{G} \& \mathbf{T}$; under usual circumstances it is supplemented with $25 \mu \mathrm{g}$. L-histidine monohydrochloride/ml. and $0.5 \%$ (w/v) glucose $\left(\mathrm{H}^{+}\right.$medium). When lactose was used it was always filtered to sterilize through Pyrex UF fritted glass disks and added separately. Also utilized were crystalline $\mathbf{K}$ penicillin $\mathbf{G}$ (Lilly) and penicillinase (Schenley). Growth was allowed under standing conditions at $37^{\circ}$.

Counts of the total number of bacteria were made with a Petroff-Hausser counting chamber; viable counts were made by plating 0.1-0.3 ml. samples of appropriate dilutions on $\mathrm{H}^{+}$medium solidified with $2 \%(\mathrm{w} / \mathrm{v})$ Difco-Bacto-agar. All figures are corrected for the volume changes that occurred during incubation of the liquid cultures despite attempts to prevent evaporation by the use of a moist incubator.

Nuclear counts were made of organisms fixed in osmic-acid vapour, hydrolysed in $\mathrm{HCl}$ and stained with Giemsa by usual techniques. Differential counts of lactose-utilizing $\left(\mathrm{lac}^{+}\right)$and non-utilizing $\left(\mathrm{lac}^{-}\right)$bacteria were made by spreading on the surface of Difco-Endo-agar.

The standard stationary phase of histidine-starved $h^{-}$bacteria was achieved by inoculating $c .50$ washed organisms ( 2 centrifugations and 2 resuspensions in $0.9 \%(\mathrm{w} / \mathrm{v})$ saline) into $2 \mathrm{ml}$. of $\mathbf{G} \& \mathbf{T}$ medium in small test tubes containing $0.5 \%(\mathrm{w} / \mathrm{v})$ glucose but only $0.25 \mu \mathrm{g}$. histidine. Several hundred such cultures were usually employed in each experiment. Other stationary phases are described in the appropriate places.

The stock solution of artificial enrichment used contained: $\beta$-alanine, phenyl alanine, arginine, aspartic acid, glutamic acid, glycine, hydroxyproline, isoleucine, leucine, lysine, methionine, proline, serine, tryptophan tyrosine, and valine in L-form, $200 \mu \mathrm{g}$. of each $/ \mathrm{ml}$.; L-cystine, $500 \mu \mathrm{g} . / \mathrm{ml}$.; L-threonine; $400 \mu \mathrm{g} . / \mathrm{ml}$;; adenine, guanine, hypoxanthine, thymine, uracil, xanthine, adenylic acid, cytidylic acid, uridylic acid, Na guanylate, adenosine and guanosine, $200 \mu \mathrm{g}$. of each $/ \mathrm{ml}$; choline, $50 \mu \mathrm{g} . / \mathrm{ml}$.; riboflavin, $4 \mu \mathrm{g} . / \mathrm{ml}$.; nicotinic acid, panthothenic acid P-aminobenzoic acid" and pyridoxine, $2 \mu \mathrm{g}$. of each $/ \mathrm{ml}$; folic acid, $0.2 \mu \mathrm{g} . / \mathrm{ml}$.; thiamin, $0.02 \mu \mathrm{g} . / \mathrm{ml}$.; biotin, $2 \times 10^{-6} \mu \mathrm{g} . / \mathrm{ml}$. The mixture was brought to $\mathrm{pH} 7$ and usually $0.1 \mathrm{ml}$. was added to $2 \mathrm{ml}$. of bacterial suspension.

The supersonic lysate was kindly prepared by Brother C. Leonard of Manhattan College. The cultures were treated for $30 \mathrm{~min}$. and the $\mathrm{h}^{-} \mathrm{lac}^{+}$bacteria employed showed a survival of $c .2 \times 10^{-4}$. Thus in the $0.1 \mathrm{ml}$. samples usually added to $2 \mathrm{ml}$. cultures there were $c .4 \times 10^{5} \mathrm{~h}^{-}$lac ${ }^{+}$bacteria capable of forming colonies.

The procedure for measuring $\beta$-galactosidase activity was basically that of Cohn \& Torriani (1953). Washed suspensions of bacteria were treated with $0.02 \mathrm{ml}$. toluene and $40 \mu \mathrm{g}$. $\mathrm{Na}$ deoxycholate $/ 4 \mathrm{ml}$. and agitated at $37^{\circ}$ for $20 \mathrm{~min}$. No extraction of the enzyme was attempted. Three ml. of the resulting 
suspension were mixed with $0.75 \mathrm{ml}$. $\mathrm{M} / 75$ o-nitrophenylgalactoside in $\mathrm{M} / 2 \mathrm{NaCl}$ : The colour resulting from hydrolysis of this compound was measured at c. $27^{\circ}$ in a Beckman spectrophotometer at $420 \mathrm{~m} \mu$.

\section{RESULTS}

The condition of bacteria during a growth factor controlled stationary phase was studied in experiments in which at intervals viable and total counts and cytological observations on size of organism and nuclear numbers were made. Figure 1 shows a sample of the results obtained. Although the total number of organisms remained constant, the number of bacteria capable of forming colonies on $\mathrm{H}^{+}$medium decreased exponentially with a rate constant $(k)$ of c. $2 \times 10^{-2} /$ bacterium $/ \mathrm{hr}$. as determined by the formulation

$$
N=N_{0} e^{-k t},
$$

where $N_{0}$ is the number of bacteria at time 0 and $N$ the number at time $t$ in hr. The average number of nuclei and the size of organisms remained unaltered for hundreds of $\mathrm{hr}$., but the fraction of bacteria surviving eventually became so small that it was not possible to know from these observations whether that fraction differed from the remainder. No matter whether the stationary phase was induced by allowing the bacteria to remain in the medium from which they exhausted the histidine themselves or whether bacteria grown in excess histidine were washed and suspended in medium devoid of that amino acid, results of the sort shown in Fig. 1 were obtained.

Cultures containing only $10^{7}$ bacteria $/ \mathrm{ml}$. barely show turbidity to the naked eye. When turbid cultures achieved by growing $h$ - bacteria in the presence of an excess of histidine until glucose was exhausted were investigated at different times during the stationary phase, the results shown on the top line of Fig. I were obtained. No significant decrease in turbidity occurred, even after $300 \mathrm{hr}$. There appeared to be no appreciable net increase in the amount of cytoplasm, and from the observations made on nuclear number it would seem that the same might have been true of DNA.

The most evident change was the loss of viability with time, which usually occurred at an exponential rate. In some experiments, after an initial phase of exponential death, the number of viable bacteria suddenly increased significantly only to decrease exponentially again. Sometimes this cycle occurred several times. It might have represented some process of recovery or perhaps a fragmentation (there is more than one nucleus per cell). It occurred even in the presence of lethal concentrations of penicillin and did not therefore result from the usual kind of growth and division of survivors. Inasmuch as it occurred only infrequently and especially because the experiments to be reported indicated that normal growth and cell division did not occur in the stationary phase, the phenomenon was not further investigated.

Under conditions of starvation for histidine such as these, where there was an excess of glucose and the salt constituents of $G \& T$, the average rate of 
mutation $(\mu)$ was $1.2 \times 10^{-9} /$ surviving bacterium $/ \mathrm{hr}$. when calculated from the formulation

$$
\mu=\frac{k m}{N_{0}\left(1-e^{-k t}\right)},
$$

where $k$ is the death rate constant, $m$ the average number of mutations from time 0 to time $t$, and $N_{0}$ the number of bacteria at time 0 minus $27 \mathrm{hr}$., the time required from the mutational event until turbidity is manifested. This chance of mutation is constant with time (Ryan, 1955 a).

In experiments to be reported in the next section the degree of growth was either limited by the simultaneous exhaustion of glucose and histidine or low concentrations of bacteria were suspended, after washing, in medium free from glucose and histidine. In the former case, growth of an inoculum of $c .50$ washed $\mathrm{h}^{-}$bacteria took place in $2 \mathrm{ml}$. lots of medium supplemented with only $0.095 \mu \mathrm{g}$. of histidine and $1.5 \mu \mathrm{g}$. of glucose per culture. The final number of bacteria per culture under these conditions was $c .2 \times 10^{7}$ and experiments in which either glucose, histidine, or both were added after growth had ceased indicated that, within the limits of measurement, both glucose and histidine were simultaneously exhausted (Table 1). Certainly after not too many hours in the stationary phase the medium was completely freed of these substances because of the metabolism of the stationary-phase bacteria. Equal-sized populations of $\mathrm{h}^{-}$bacteria in some histidine-limited stationary phases consume in $1 \mathrm{hr}$. more glucose than was initially added to the cultures under discussion (Ryan \& Schneider, 1949b). During this doubly limited stationary phase there was a very slow rate of death; after $300 \mathrm{hr}$. more than $60 \%$ of the bacteria still survived. The $\mathrm{h}^{+}$mutants present could not grow, of course, because of the

Table 1. Sample experiment demonstrating the simultaneous exhaustion of glucose and histidine from cultures initially containing $1.5 \mu \mathrm{g}$. of glucose and $0.095 \mu \mathrm{g}$. histidine and inoculated with c. $5000 \mathrm{~h}^{-}$bacteria

$\begin{array}{lcc}\begin{array}{c}\text { Supplement added } 66 \mathrm{hr} . \\ \text { after inoculation }\end{array} & \begin{array}{c}\text { Time of } \\ \text { plating }(\mathrm{hr} .)\end{array} & \begin{array}{c}\text { No. of } \mathrm{h}-\text { bacteria } \\ \text { developed }\end{array} \\ \text { None } & 66 & 2 \cdot 4 \times 10^{7} \\ \text { None } & 116 \cdot 3 & 2 \cdot 4 \times 10^{7} \\ \text { 1 mg. glucose } & 116 \cdot 3 & \mathbf{3 \cdot 0} \times 10^{7} \\ 50 \mu \text { g. histidine } & 116 \cdot 3 & 2 \cdot 4 \times 10^{7} \\ 1 \text { mg. glucose + 50 } \mu \mathrm{g} . & 116 \cdot 3 & 2 \cdot 2 \times 10^{8} \\ \text { histidine } & & \end{array}$

absence of glucose. After an average of $430 \mathrm{hr}$. in three experiments, when excess glucose was added, the number of adaptations observed was accountable in terms of the mutants which arose during initial growth and gave no evidence of mutations having occurred during the stationary phase. For example, when glucose was added at $41 \mathrm{hr}$., 188 of 300 cultures proved to contain $\mathrm{h}^{+}$mutants by adapting; when added at $c .430 \mathrm{hr}$., only 158 of $299 \mathrm{cul}$ tures adapted. When an estimate was made of the number of $\mathrm{h}^{+}$mutants that would survive, assuming they died during the stationary phase at the same rate as their $\mathrm{h}^{-}$parents, it could be calculated that 150 of the original 188 cul- 
tures containing mutants should still possess viable $\mathrm{h}^{+}$cells. This number is not significantly different from the 158 observed after $430 \mathrm{hr}$. $\left(P\right.$ from $\left.\chi^{2}=0 \cdot 6\right)$. Therefore if mutations from $\mathrm{h}^{-}$to $\mathrm{h}^{+}$did occur during this histidine- and sugar-starved stationary phase, they were not frequent. Markovich (private communication) has observed the same result.

In other experiments cultures containing $c .2 \times 10^{7}$ bacteria and devoid of glucose and histidine were made to contain $0.5 \%(\mathrm{w} / \mathrm{v})$ sterile-filtered lactose which was added after the stationary phase began. In such a stationary phase death did not usually occur even after c. $300 \mathrm{hr}$. (Table 2), but mutations took place at a low rate. The bacterial population usually consisted of a 50:50 mixture of $\mathrm{h}^{-} \mathrm{lac}^{+}$and $\mathrm{h}^{-}$lac- strains. The $\mathrm{h}^{+} \mathrm{lac}^{+}$mutants were able to utilize the lactose present and overgrew the cultures in which they occurred, causing a visible turbidity; whatever $\mathrm{h}^{+}$lac$^{-}$mutants arose were not detected for the adaptive overgrowths were never caused by lac ${ }^{-}$bacteria. The rate of mutation $/ \mathrm{h}^{-}$lac ${ }^{+}$bacterium $/ \mathrm{hr}$. $(\mu)$ could be calculated by the equation

$$
\mu=\frac{m}{N t},
$$

where $m$ is the average number of mutations to $\mathrm{h}^{+}$lac $\mathrm{c}^{+}$occurring from time 0 to time $t$, and $N$ is the average number of $\mathrm{h}^{-}$lac ${ }^{+}$bacteria present during that period when death did not occur. Time 0 is set $27 \mathrm{hr}$. after the addition of lactose in order to exclude from measurement those mutants which arose during growth and which require that number of hours to overgrow (Ryan, 1955a). To calculate $m$ the zero term of the Poisson formulation (1) is used, where $\boldsymbol{P}_{(0)}$ is the frequency of unadapted cultures without $\mathrm{h}^{+} \mathrm{lac}^{+}$mutants.

Table 2. The behaviour of mixtures of $h-l a c^{+}$and $h-l a c^{-}$bacteria in a stationary phase in $G \& T$ medium where glucose and histidine were absent but $0.5 \%$ $(w / v)$ lactose was present

The number of viable bacteria was determined by plating on Endo-agar where the lacand lac ${ }^{+}$colonies could be differentiated.

$\begin{array}{cccc}\text { Time (hr.) } & \begin{array}{c}\text { No. of viable } \\ \text { bacteria }\end{array} & \begin{array}{c}\text { \% lac } \\ \text { bacteria }\end{array} & \begin{array}{c}\text { Total no. of } \\ \text { bacteria }\end{array} \\ 0 & 2.0 \times 10^{7} & 61.2 & 2.4 \times 10^{7} \\ 48.5 & 1.7 \times 10^{7} & 54.7 & 1.3 \times 10^{7} \\ 99.3 & 2.1 \times 10^{7} & 58.6 & 1.4 \times 10^{7} \\ 145 \cdot 1 & 2.2 \times 10^{7} & 52.7 & 1.9 \times 10^{7} \\ 192.3 & 2.0 \times 10^{7} & 55.5 & - \\ 239.3 & 1.5 \times 10^{7} & 50.0 & - \\ 289.9 & 1.9 \times 10^{7} & 54.3 & - \\ \text { Av. } & 1.9 \times 10^{7} & 55.3 & 1.8 \times 10^{7}\end{array}$

In five experiments where the average total number of cells per culture was $1.6 \times 10^{7}$, of which $57.9 \%$ were $\mathrm{h}^{-} \mathrm{lac}^{+}$, the average mutation rate $(\mu)$ was $1.2 \times 10^{-10}$ and was constant with time (Table 3). In three experiments where the only bacteria present were $\mathrm{h}^{-} \mathrm{lac}^{+}$and their number was on the average $1.3 \times 10^{7}$, the average mutation rate was also $1.2 \times 10^{-10}$. These rates 
are significantly lower than those found in $\mathrm{h}^{-}$cultures with an excess of glucose where death occurs. The decreased rate was not caused by the failure of the $\mathrm{h}^{+}$mutants to adapt to the lactose present and hence to overgrow. The addition of excess glucose or of an enrichment consisting of vitamins, amino acids and nucleic acid derivatives did not induce the overgrowth of accumulated but cryptic $h^{+}$mutants in histidine-starved cultures of $h^{-}$bacteria to

Table 3. Constancy of the chance of mutation of $h^{-l a c}+$ bacteria to the $h^{+}$lac $^{+}$ condition in mixtures containing $27.9 \% h-l a c-$ bacteria and $0.5 \%(w / v)$ lactose buit no histidine

The total number of bacteria was $1 \cdot 1 \times 10^{7} / 2 \mathrm{ml}$. culture.

Time in

\section{stationary}

phase (hr.)

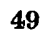

72

144

168

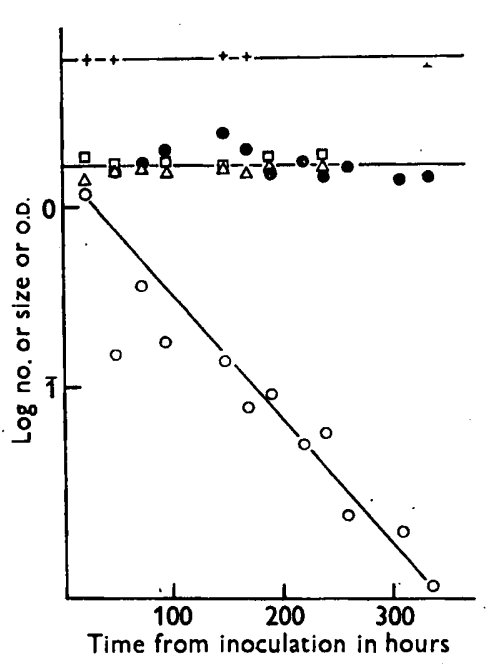

Fig. 1
Average no. of mutations $(m)$

$0 \cdot 10$

$\mathbf{0} \cdot \mathbf{1 5}$

$0 \cdot 22$

$0 \cdot 32$
Mutation rate/

bacterium $/ \mathbf{h r}$.
Fig. 1. The properties of $h^{-}$bacteria in a stationary phase brought about by the exhaustion of histidine alone. About $50 \mathrm{~h}$ - bacteria were inoculated into $2 \mathrm{ml}$. lots of $\mathrm{G} \& \mathrm{~T}$ medium containing $0.5 \%$ glucose $(\mathrm{w} / \mathrm{v})$ and $0.25 \mu \mathrm{g}$. histidine, and incubated standing at $37^{\circ}$. O, number of viable $\mathrm{h}^{-}$bacteria $\times 10^{7}$ tested by plating on $\mathrm{H}^{+}$medium; total number of bacteria $\times 10^{7}$ as determined in a Petroff-Hausser counting-chamber; $\triangle$, average number of DNA-containing bodies/bacterium; $\square$, average length in microns of the stained bacteria. The crosses represent the optical density in Klett units $\times 10^{1}$ of $10 \mathrm{ml} . \mathrm{h}^{-}$cultures which had been grown to a glucose-limited stationary phase in the presence of $25 \mu \mathrm{g}$. histidine $/ \mathrm{ml}$. All figures are corrected for the slight volume changes that occurred despite attempts to prevent them by the use of a moist chamber.

Fig. 2. The change in $\beta$-galactosidase activity of histidine-starved $h-$ lac + bacteria in the presence of lactose. The activity is measured in optical density units $/ \mathrm{min} . / 10^{7} \mathrm{~h}-\mathrm{lac}^{+}$ bacteria; the abscissa is time in hr. from the addition of lactose to the glucose-grown cells. 
which lactose had been added. Nor was the low mutation rate a function of a spurious survival curve due to the use of Endo-agar as a plating medium in the experiments described in Table 2 , because. when bacteria suspended in lactose were plated on ordinary $\mathrm{H}^{+}$medium with glucose the mutation rate $(\mu)$ in 16 experiments still averaged $1.3 \times 10^{-10}$.

Under these conditions of plating there usually was a barely detectable death $\left(k=c .2 \times 10^{-3}\right)$. The bacteria, although initially unadapted to lactose because of their growth on glucose (residual activity, $0.02 \mathrm{o.D}$. units $/ \mathrm{min} . / 10^{7}$ bacteria), gradually developed $\beta$-galactosidase activity (see also Mandelstam, 1957,1958 ) until a maximum of $c .40 \%$ of the activity of fully adapted cells (2.6 o.D. units/min./10 $10^{7}$ bacteria) was achieved. Thereafter, the activity per cell decreased (Fig. 2). The $\mathrm{h}^{+}$mutants arising in the presence of lactose developed full activity equal to that of $\mathrm{h}$ - bacteria grown in the presence of lactose. Perhaps, in contrast to glucose-grown cells suspended in glucose medium, it is the fact that a maximally vigorous metabolism is never achieved that prevents unadapted bacteria (and, of course, $h^{-}$lac $^{-}$as well) from dying in the presence of lactose and from mutating more rapidly than they do. When $\mathrm{h}^{-} \mathrm{lac}^{+}$ bacteria were grown to histidine starvation in the presence of excess lactose so that they were fully adapted to use that sugar, they underwent rapid death in the stationary phase $\left(k=1.7 \times 10^{-2}\right)$, and their mutation rate to $\mathrm{h}^{+}$was $3.8 \times 10^{-9} /$ bacterium $/ \mathrm{hr}$. In these respects they resembled glucose-grown cells in the presence of glucose.

Table 4. Example of an experiment in which the percentage of new growth that is lac ${ }^{+}$decreased with the time at which optimal amounts of histidine were added to histidine-starved mixtures of $h^{-}$lac ${ }^{+}$and $h^{-}$lac ${ }^{-}$bacteria metabolizing lactose alone

$\begin{array}{cc}\begin{array}{c}\text { Time of } \\ \text { addition of } \\ \text { histidine (hr.) }\end{array} & \begin{array}{c}\text { Percentage of } \\ \text { new growth: } \\ \text { resulting that } \\ \text { was lac }\end{array} \\ 0 & 95 \cdot 4 \\ 24 & 90 \cdot 9 \\ 44 & 79 \cdot 6 \\ 96 & 72 \cdot 1 \\ 140 & 58 \cdot 1\end{array}$

During the stationary phase, in the absence of glucose and histidine but in the presence of lactose, a carbon source may accumulate that can be used by $h^{-l a c}-$ bacteria. This was demonstrated when mixtures of $h^{-l a c}{ }^{-}$and $h^{-}$lac $^{+}$ bacteria in this condition were supplied with optimal amounts of histidine. The new growth that resulted may be composed of increasing percentages of lacbacteria as the time in the stationary phase before histidine addition increases (Table 4), but this increase could not be observed in all experiments. Although this carbon source may consist of organic acids produced from the lactose by the $\mathrm{h}^{-}$lac $^{+}$bacteria, its chemical nature was not identified. It was present in sufficient amounts, however, to support the maximal growth of $h^{-}$lac ${ }^{-}$ bacteria inoculated into sterile-filtered medium containing it and $0.07 \mu \mathrm{g}$. 
of added histidine $/ 2 \mathrm{ml}$. These bacteria might be supposed to be adapted to use this carbon source, but in the ensuing stationary phase they did not die for at least $75 \mathrm{hr}$. and they mutated to $\mathrm{h}^{+}$at a rate of $1.2 \times 10^{-10}$.

\section{Experiments to detect a possible cell turnover}

How a turnover of cells occurring with a $100 \%$ efficiency can be demonstrated directly if it takes place in the stationary phase in liquid medium is not obvious. It is possible, however, to approach the problem indirectly by several methods. The first depends upon a selective increase on the part of $\mathrm{h}^{-}$lac $^{+}$ bacteria in a stationary phase system also containing $\mathrm{h}^{-}$lac- bacteria and lactose, where lysis of both types might confer a selective advantage on the $\mathrm{h}^{-}$lac $^{+}$component during replacement. The second involves assumptions about the enzyme $\beta$-galactosidase in adapted cells in a stationary phase devoid of lactose. A third anticipates death in the presence of penicillin of the cells that replace those assumed to have lysed. Fourth, it can be asked whether the mutations from $\mathrm{h}^{-}$to $\mathrm{h}^{+}$will take place in the presence of concentrations of penicillin that will kill growing cells. Finally, direct observations of histidinestarved $\mathrm{h}^{-}$cells on the surface of agar may be made microscopically.

Such direct observations could not be made in liquid medium containing Methocel because it was found impossible to remove contaminating traces of histidine. Similarly, the use of mechanical, absorptive, or enzymic devices to remove any histidine that might be released by the hypothesized lysis failed to illuminate the problem for reasons of technique or the interfering presence of residual histidine. Further, the steady-state concentration of histidine was, as might have been expected, too small to detect in supernatants by assay with $\mathrm{h}^{-}$bacteria. The fraction of cells containing one or more units of the permease required for lactose assimilation would be expected to decrease upon lysis of some cells and replacement by others in the absence of an inducer (see Novick \& Wiener, 1957); these experiments have not yet been completed.

\section{Mixtures of $h^{-} \mathrm{lac}^{+}$and $h^{-}$lac $^{-}$bacteria}

Cryptic growth of bacterial populations might be detected in the histidinestarved stationary phase if there were a selective advantage conferred upon the lac ${ }^{+}$component of a mixture of $\mathrm{h}^{-} \mathrm{lac}^{-}$and $\mathrm{h}^{-} \mathrm{lac}^{+}$bacteria. Such an advantage might be obtained if, for example, lactose were the only carbon source present; in such an event the lac ${ }^{+}$component would be expected to increase in proportion as it selectively replaced the lac $^{-}$and lac $^{+}$bacteria presumed to lyse by utilizing the histidine they released and lactose. Lactose fermentation is not extracellular, as has been shown by Benzer (1953) and as is demonstrated by the existence of sharply-sectored colonies on Endo agar.

When mixtures of $\mathrm{h}^{-} \mathrm{lac}^{-}$and $\mathrm{h}^{-}$lac $^{+}$were grown to levels of $c .2 \times 10^{2}$ / $2 \mathrm{ml}$. in medium that became, as a result, exhausted of histidine and glucose and to which lactose was added, a significant shift in the proportion of the lac ${ }^{+}$ component did not occur even after $c .300 \mathrm{hr}$. (Table 2). Attempts were made to determine whether there was in fact a selective advantage in favour 
of the lac ${ }^{+}$bacteria. Upon the addition of optimal amounts of histidine to the mixtures in a histidine-starved stationary phase, anything from 58 to $100 \%$ of the new growth resulting, according to the time of addition, consisted of lac ${ }^{+}$ bacteria (Table 4). When histidine was accompanied by an optimal amount of glucose, only $\mathbf{5 9 \%}$ of the new growth was lac ${ }^{+}$; this result is understandable because both the $\mathrm{h}^{-} \mathrm{lac}^{+}$and the $\mathrm{h}^{-}$lac $^{-}$were adapted to use glucose. In order to make the added carbon source more closely resemble that which might be produced by the hypothesized lysis but cannot be reproduced exactly, either an artificial enrichment consisting of vitamins, amino acids and nucleic acid derivatives, or an actual lysate produced by supersonic vibration, was employed. Both these enrichments supported maximal amounts of growth with no added carbon source. In the former case, $2-5 \times 10^{-1} \mu \mathrm{g}$. histidine was added either with the enrichment in the early stationary phase or some $100 \mathrm{hr}$. later. The supersonic-lysate, on the other hand, contained enough histidine to support the growth of $2.3 \times 10^{7} \mathrm{~h}$ - bacteria; this histidine was limiting because, as a carbon source in the presence of excess histidine, the same volume of lysate (0.1 ml.) supported the growth of $6.7 \times 10^{7}$ bacteria. Although new growth was initiated in both cases, the lac ${ }^{-}$and lac $^{+}$bacteria fared equally well; they grew for the same number of generations at indistinguishable rates until the histidine was exhausted. Therefore, these experiments provided no test of the hypothesis; the $\beta$-galactosidase developed in the stationary phase conferred no advantage on the lac ${ }^{+}$bacteria.

It was otherwise when the $\mathrm{h}^{-} \mathrm{lac}^{+}$bacteria were previously grown on, and adapted to, lactose and then mixed in the presence of excess lactose with glucose-grown $\mathrm{h}^{-}$lac- $^{-}$bacteria. Either enrichment in this event allowed a selective increase in the proportion of $\mathrm{h}^{-} \mathrm{lac}^{+}$bacteria in the presence of limiting amounts of histidine (Fig. 3). Experiments under each condition showed that both rates of growth and numbers of generations were $c .1 .5 \times$ as great for the lac ${ }^{+}$component (Table 5).

When $\mathrm{h}^{-} \mathrm{lac}^{+}$bacteria were grown on $2 \times 10^{-2} \mu \mathrm{g}$. histidine $/ 2 \mathrm{ml}$. and $0 \cdot 1 \%$ $(\mathrm{w} / \mathrm{v})$ lactose for $70 \mathrm{hr}$. they became fully adapted to use that sugar. Upon mixing $1 \mathrm{ml}$. of them with $1 \mathrm{ml}$. of a suspension of $\mathrm{h}^{-}$lac- bacteria, grown for the same time on $2 \times 10^{-2} \mu \mathrm{g}$. histidine and $1.5 \mu \mathrm{g}$. glucose $/ 2 \mathrm{ml}$., in large numbers of small tubes, there remained an excess of unused lactose. After the addition of $0.1 \mathrm{ml}$. of artificial enrichment, results were obtained of which those shown in Fig. 4 are a sample. The initial proportion of $\mathrm{h}^{-} \mathrm{lac}^{+}$bacteria $(14 \%)$ dropped during the first $50 \mathrm{hr}$. to a level of $5 \%$, presumably because the $\mathbf{h}^{-}$lac $^{+}$, adapted to use lactose, began to die immediately through metabolizing it, while the $\mathrm{h}^{-}$lac $^{-}$began to die only after some $50 \mathrm{hr}$. when they had adapted to use the enrichment. Thereafter the proportion of lac ${ }^{+}$remained constant at c. $3 \%$ until after $250 \mathrm{hr}$. they seemed to have disappeared from the tubes sampled. Both $\mathrm{h}^{-} \mathrm{lac}^{-}$and $\mathrm{h}^{-} \mathrm{lac}^{+}$seemed to die with a rate constant $(k)$ of $2.7 \times 10^{-2}$ until sampling became inaccurate.

The fact that the excess of $\mathrm{h}^{-}$lac $^{+}$predicted was not realized speaks against the hypothesis of turnover. None the less, it is possible that the rate of death of the lac ${ }^{+}$bacteria was in reality greater than that of the lac- bacteria, the 
apparent equality resulting from a coincidental balance through replacement by lac ${ }^{+}$of the lysing lac- bacteria.

Even when the $\mathrm{h}^{-} \mathrm{lac}^{+}$and $\mathrm{h}^{-} \mathrm{lac}^{-}$mixture was suspended in lactose alone without enrichment, death of the $\mathrm{h}^{-} \mathrm{lac}^{+}$bacteria occurred because they were able to metabolize the lactose (Fig. 5). The rate of death $\left(2 \times 10^{-2} / \mathrm{hr}\right.$.) was indistinguishable from that of $\mathrm{h}^{-} \mathrm{lac}^{+}$bacteria suspended alone without $\mathrm{h}^{-}$lacin an excess of lactose. Attempts were made, with the generous assistance of Mr Richard Levins and Dr Pinchas Mendelson, to predict the rate of decrease in the $\mathrm{h}^{-}$lac ${ }^{+}$component of the mixed population on the assumptions that:

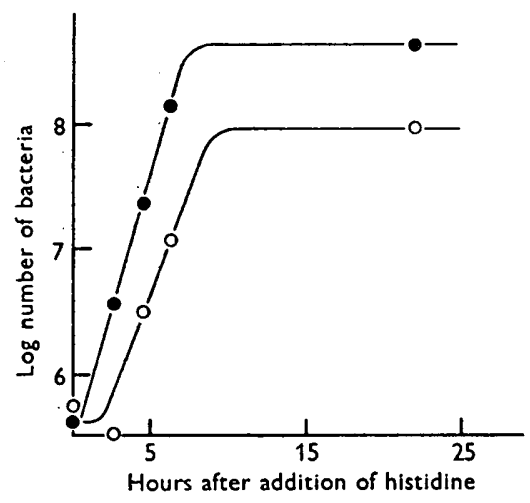

$a$

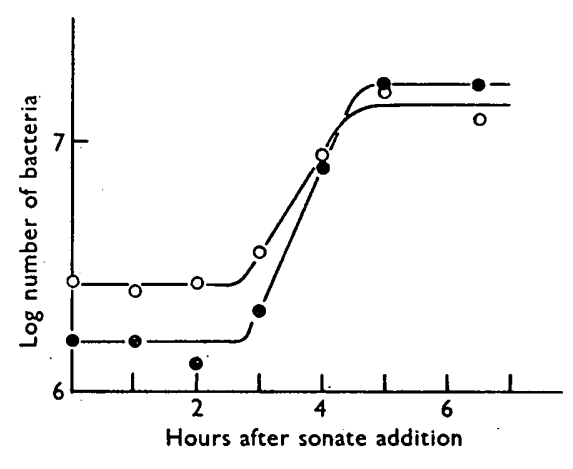

$\boldsymbol{b}$

Fig. 3. Increase of $\mathrm{h}^{-} \mathrm{lac}^{-}$and $\mathrm{h}^{-}$lac + bacteria in histidine-starved mixtures in the presence of lactose and an enrichment upon the addition of limiting amounts of histidine. (a) $\mathrm{h}^{-}$lac + bacteria grown on $2 \times 10^{-2} \mu \mathrm{g}$. histidine and $0.1 \%(\mathrm{w} / \mathrm{v})$ lactose $/ 2 \mathrm{ml}$. and $\mathrm{h}^{-} \mathrm{lac}-$ bacteria on $2 \times 10^{-2} \mu \mathrm{g}$. histidine and $1.5 \mu \mathrm{g}$. glucose $/ 2 \mathrm{ml}$. for $70 \mathrm{hr}$., whereupon the two strains were mixed by adding $1 \mathrm{ml}$. of each to $147 \mathrm{small}$ tubes which also received $0.1 \mathrm{ml}$. of an artificial enrichment (see text); $96 \mathrm{hr}$. later $5 \times 10^{-1} \mu \mathrm{g}$. histidine were added to each tube. (b) Bacteria grown as in $(a)$ but $\mathrm{h}^{-} \cdot \mathrm{lac}^{+}$on $4 \times 10^{-2} \mu \mathrm{g}$. histidine; after $67 \mathrm{hr}$., $0 \cdot 1 \mathrm{ml}$. supersonic lysate, which contained histidine sufficient to support the growth of $2.3 \times 10^{7} \mathrm{~h}^{-}$bacteria, was added. $O=$ lac- bacteria; $O=$ lac $^{+}$bacteria.

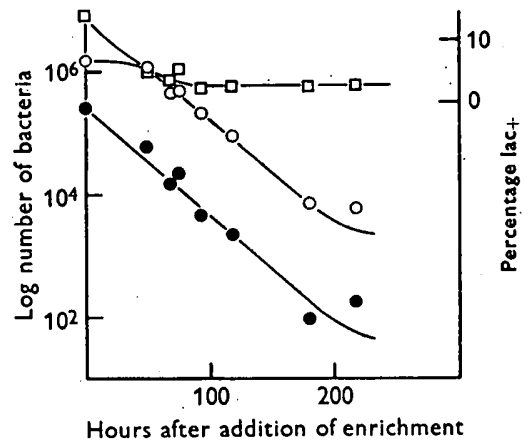

Fig. 4. The behaviour of $\mathrm{h}^{-} \mathrm{lac}^{-}$and adapted $\mathrm{h}^{-}$lac ${ }^{+}$bacteria mixed in lactose and an artificial enrichment (see test). The experiment was set up as described in the caption of Fig. 3a. O, $\mathrm{h}^{-}$lac $^{-}$bacteria;, $\mathrm{h}^{-}$lac ${ }^{+}$bacteria adapted to lactose; $\square, \% \mathrm{~h}^{-}$lac $^{+}$ bacteria. 
(1) The mutations observed occurred among cells that were growing in the process of replacing other cells that had lysed.

(2) The mutation rate among these cells was the same per bacterium per generation as among cells undergoing unrestricted growth (i.e. $a=3 \times 10^{-8}$ ).

(3) From these assumptions, and a knowledge of the rates of mutation of

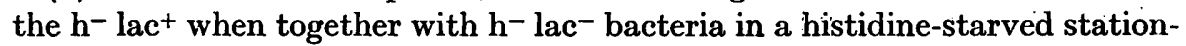
ary phase and a knowledge of the number of cells per culture, the rate of replacement $(\beta)$ could be calculated.

(4) The histidine released by lysis was immediately consumed by replacement so that for each component strain maintained separately the rate of replacement $(\beta)$ equalled the rate of lysis $(\alpha)$ : because the total number of bacteria remained constant.

(5) In mixed suspension the histidine released was divided among the cells present in proportion to their numbers and to the efficiencies of utilization $(\gamma)$ measured in the presence of lysate and larger, but still limiting, amounts of histidine (Table $5 ; k_{1}$ for $\mathrm{h}^{-}$lac $^{+}=0.57 ; k_{2}$ for $\mathrm{h}^{-}$lac $\mathrm{l}^{-}=0.43$ ).

Table 5. Rates of growth and of numbers of generations passed through by $h^{-}$lacand lactose-adapted $h^{-}$lac $^{+}$components of histidine-starved mixtures in the presence of lactose and an enrichment upon the addition of limiting amounts of histidine

Artificial enrichment (see text)

\begin{tabular}{|c|c|c|c|c|c|c|c|c|c|}
\hline \multirow[t]{2}{*}{$\begin{array}{l}\mu \mathrm{g} . \text { histidine } \\
\text { added to } 2 \mathrm{ml} \text {. }\end{array}$} & \multicolumn{2}{|c|}{$\begin{array}{l}\text { Generation } \\
\text { time (min.) }\end{array}$} & \multicolumn{2}{|c|}{$\begin{array}{c}\text { No. of } \\
\text { generations } \\
\text { of growth. }\end{array}$} & \multirow{2}{*}{$\begin{array}{c}\text { Ml. } \\
\text { lysate } \\
\text { added } \\
\text { to } \\
2 \mathrm{ml} .\end{array}$} & \multicolumn{2}{|c|}{$\begin{array}{l}\text { Generation } \\
\text { time (min.) }\end{array}$} & \multicolumn{2}{|c|}{$\begin{array}{c}\text { No. of } \\
\text { generations } \\
\text { of growth }\end{array}$} \\
\hline & lac- & $\mathrm{lac}^{+}$ & $\mathrm{lac}^{-}$ & $\mathrm{lac}^{+}$ & & $\mathrm{lac}^{-}$ & $\mathrm{lac}^{+}$ & $\mathrm{lac}^{-}$ & lact $^{+}$ \\
\hline $\begin{array}{l}5 \times 10^{-1} \\
3 \times 10^{-1}\end{array}$ & $\begin{array}{l}54 \\
68\end{array}$ & $\begin{array}{l}45 \\
38\end{array}$ & $\begin{array}{l}7 \cdot 6 \\
6 \cdot 6\end{array}$ & $\begin{array}{r}9 \cdot 0 \\
10 \cdot 0\end{array}$ & $\begin{array}{l}0.2 \\
0 \cdot 1\end{array}$ & $\begin{array}{l}49 \\
55\end{array}$ & $\begin{array}{l}40 \\
38\end{array}$ & $\begin{array}{l}6 \cdot 1 \\
2 \cdot 6\end{array}$ & $\begin{array}{l}7 \cdot 1 \\
3 \cdot 6\end{array}$ \\
\hline $2 \times 10^{-1}$ & 68 & 38 & $6 \cdot 0$ & $8 \cdot 1$ & - & - & - & - & - \\
\hline
\end{tabular}

(6) The rates of death without lysis $(k)$ were constant and the same as those observed when each component strain was separate.

From these we can write

$$
\begin{aligned}
& \frac{d N^{+}}{d t}=k_{1} N^{+}-\alpha_{1} N^{+}+\frac{\gamma_{1} N^{+}\left(\alpha_{1} N^{+}+\alpha_{2} N^{-}\right)}{\gamma_{1} N^{+}+\gamma_{2} N^{-}}, \\
& \frac{d N^{-}}{d t}=-k_{2} N^{-}-\alpha_{2} N^{-}+\frac{\gamma_{2} N^{-}\left(\alpha_{1} N^{+}+\alpha_{2} N^{-}\right)}{\gamma_{2} N^{-}+\gamma_{1} N^{+}},
\end{aligned}
$$

where $\mathrm{N}^{+}$and $\mathrm{N}^{-}$are the number of $\mathrm{h}^{-} \mathrm{lac}^{+}$and $\mathrm{h}^{-}$lac- $^{-}$bacteria.

The expressions

$$
\frac{\gamma_{1} N^{+}}{\gamma_{1} N^{+}+\gamma_{2} N^{-}} \text {and } \frac{\gamma_{2} N^{-}}{\gamma_{2} N^{-}+\gamma_{2} N^{+}}
$$

are not stable enough to be considered constant even for periods as short as $100 \mathrm{hr}$. (from Fig. 5). Furthermore, since the constants for rate of lysis $(\alpha)$ 
are not proportional to the constants for rate of utilization $(\gamma)\left(\gamma_{1} / \gamma_{2}=1.5\right.$ but $\left.x_{1} / \alpha_{2}=20\right)$ the term $\left(\alpha_{1} N^{+}+\alpha_{2} N^{-}\right) /\left(\gamma_{1} N^{+}+\gamma_{2} N^{-}\right)$is not constant. The only way to preserve in the equations the linearity observed in Fig. 5 is to postulate a most complex interaction among the $\mathrm{h}^{-} \mathrm{lac}^{+}$and $\mathrm{h}-\mathrm{lac}^{-}$bacteria in their utilization efficiencies and a coincidental relation between the constants.

Since there appears no biological reason to do this, we must face the fact that equations (6) and (7) predict that the rate of replacement of the $h-$ lac $^{-}$ bacteria by the $\mathrm{h}^{-}$lac ${ }^{+}$would be most rapid at first and decrease with time: As a matter of fact, the slope should have almost doubled in $300 \mathrm{hr}$. and the fact that it did not indicates that the specific assumptions involved in the hypothesis of cell turnover cannot apply to the instance tested. Rather, the data indicate that the $\mathrm{h}^{-} \mathrm{lac}^{+}$and $\mathrm{h}^{-}$lac- bacteria in mixture neither lysed nor divided.

\section{The gain and loss of $\beta$-galactosidase from $h^{-}$lac ${ }^{+}$bacteria}

In the event of cell turnover, the $\mathrm{h}$ - lact cells newly formed in the presence of lactose should be induced to contain $\beta$-galactosidase. As a matter of fact, they are so induced during the histidine-starved stationary phase (Fig. 2) But whereas the $\beta$-galactosidase on the turnover hypothesis should increase at the rate of turnover (c. $2 \times 10^{-3}$ in these experiments), in reality it increased $5 \times$ as fast and then, unanticipated by the turnover hypothesis, decreased before the culture had become fully adapted. The adaptation of Escherichia

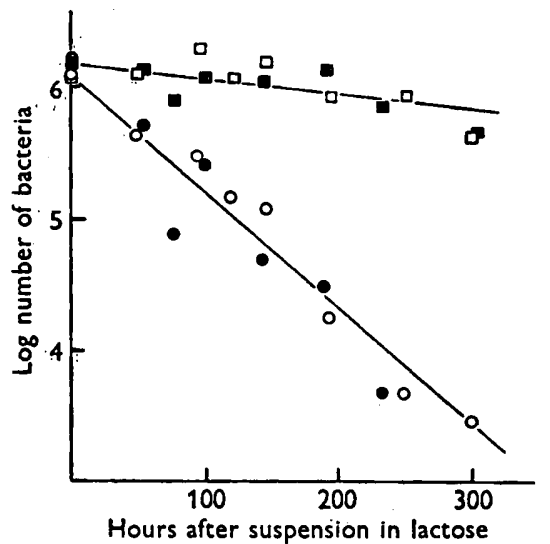

Fig. 5

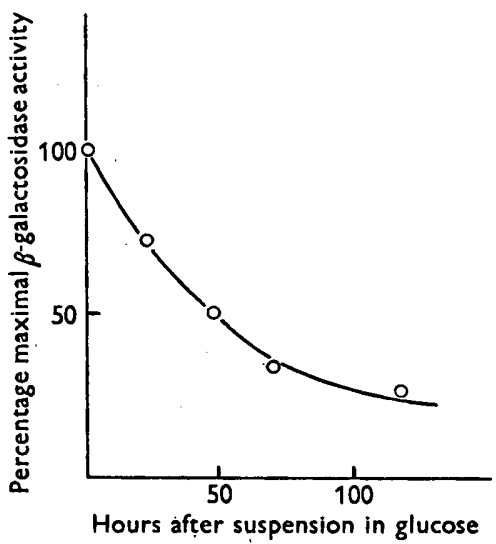

Fig. 6

Fig. 5. The behaviour of $h^{-}$lac $^{-}$and adapted $h^{-}$lac $^{+}$bacteria mixed in the presence of lactose alone. The $h^{-}$lac ${ }^{+}$bacteria were grown on $2 \times 10^{-2} \mu \mathrm{g}$. histidine $/ 2 \mathrm{ml}$. and $0.1 \%$ $(\mathrm{w} / \mathrm{v})$ lactose and the $\mathrm{h}^{-}$lac- bacteria were grown on $1 \times 10^{-2} \mu \mathrm{g}$. histidine and $0.75 \mu \mathrm{g}$. glucose $/ 2 \mathrm{ml}$. for $20 \mathrm{hr}$. before mixing. The squares represent the behaviour of the $h$ - lac- bacteria and the circles of the $h^{-}$lact bacteria, in two experiments. The $k$ for the slope of the $h^{-}$lact curve was $2.1 \times 10^{-2}$ per $h r$. , for the $h^{-}$lac- bacteria it was $1.2 \times 10^{-3}$. The mutation rates $(\mu)$ for the $h^{-}$lac- $^{-}$strain averaged $2 \times 10^{-10}$ and for the $h^{-}$lac $^{+}$strain $4 \times 10^{-9}$; the average number of bacteria per culture was $2 \times 10^{7}$.

Fig. 6. The loss of $\beta$-galactosidase activity from fully adapted $h^{-}$lac + bacteria suspended after washing in medium where the sole carbon source was glucose. Maximal activity was 2.6 o.D./units/min./10? total bacteria. 
coli to form $\beta$-galactosidase during a stationary phase has been shown by Mandelstam $(1957,1958)$ to occur without cell division; furthermore, the kinetics of the process is not in accord with the notion of cell turnover.

Conversely, fully adapted $\mathrm{h}^{-} \mathrm{lac}^{+}$cultures grown in lactose would, on the turnover hypothesis, be expected to lose their $\beta$-galactosidase at the turnover rate $\left(2 \times 10^{-2}\right.$ in this instance) when suspended in glucose which will not induce $\beta$-galactosidase in cells forming in its presence. Figure 6 shows that the $\beta$ galactosidase activity actually does decrease in initially adapted histidinestarved $\mathrm{h}^{-}$lac ${ }^{+}$bacteria suspended in glucose; and at about the anticipated rate $\left(1.7 \times 10^{-2}\right)$. Such a loss has also been described by Mandelstam (1957, 1958) for non-dividing Escherichia coli. Furthermore, because $\beta$-galactosidase is an unusually stable enzyme persisting in active form in cell lysates at $37^{\circ}$ for long times (Cohn \& Torriani, 1953), that which is lost from the $\mathrm{h}^{-} \mathrm{lac}^{+}$bacteria ought to be found in their supernatants. On the contrary, supernatants from cultures of $c .1 \cdot 2 \times 10^{7} \mathrm{~h}^{-} \mathrm{lac}^{+}$bacteria with activities initially at a level of $c .2 .5$ and which fell in $100 \mathrm{hr}$. to less than 1.0, showed activities of 0.16 at $0 \mathrm{hr}$., 0 at $25 \mathrm{hr}$., -0.04 at $50 \mathrm{hr}$. and -0.12 at $71 \mathrm{hr}$. Clearly no stable $\beta$-galactosidase had been released into the medium and consequently the hypothesis of cell turnover once more was not sustained.

\section{Addition of penicillin}

The growing cells postulated by the cell turnover hypothesis should be sensitive to penicillin, in which event replacement could not take place in its presence. Therefore, in addition to the death that occurs in the absence of penicillin, there should be an additional death at least as rapid as the rate of hypothetical lysis. It would be quite abrupt, of course; if the cells killed by penicillin also released histidine that could be used for the growth of other cells.

Table 6. The effect of penicillin on the death of histidine-starved cultures

$\begin{array}{lccc}\text { Treatment } & \text { Rate of death }(k) & \text { Range of } k & \text { Total no. of bacteria } \\ \text { None } & 0.028 & 0.015-0.038 & 2.1 \times 10^{7} \\ \begin{array}{l}\text { Penicillin }(630- \\ \text { 1300 u.) }\end{array} & 0.023 & 0.015-0.031 & 2.0 \times 10^{7} \\ \begin{array}{l}\text { Histidine }(0.125 \mu) \\ \text { Penicillin plus }\end{array} & 0.038 & 0.018-0.071 & 3.6 \times 10^{7} \\ \begin{array}{c}\text { histidine } \\ \text { Histidine at } \\ \text { intervals }\end{array} & 0.218 & 0.086-0.300 & 2.1 \times 10^{7} \\ \begin{array}{c}\text { Penicillin plus } \\ \text { histidine at } \\ \text { intervals }\end{array} & 0.028 & 0.017-0.039 & - \\ & 0.182 & 0.086-0.310 & -\end{array}$

As a test of this prediction of the turnover hypothesis, c. $50 \mathrm{~h}^{-}$bacteria were inoculated into each of several hundred $2 \mathrm{ml}$. cultures where they grew to a level of $c .2 \times 10^{7} /$ culture, limited by the exhaustion of histidine. Glucose present initially at a level of $0.5 \%(\mathrm{w} / \mathrm{v})$, remained in excess. After the $\mathrm{h}^{+}$ mutants arising during this limited growth had overgrown the cultures (48 hr.), 
a lethal concentration of penicillin was added to half of the remaining tubes, the other half serving as controls. Total and viable counts were made on members of both series and the rate of death, $k$, was determined from the slope of exponential survival curves such as are shown in Fig. 7. The rates of death under different conditions are shown in Table 6, which embodies the averages of five experiments.

It was found that penicillin alone was without effect, the rates of death being indistinguishable in the presence and absence of that antibiotic. This suggested that none of the histidine-starved cells were in the process of division and sensitive to penicillin; if $2 \%$ of the population were turning over every hr., the $k$ was expected to have been at least 0.06 in the presence of penicillin.

In order to be sure that the release of small amounts of histidine by lysis would cause an increased death rate, amounts of the order postulated were added with and without penicillin. A turnover of $c .2 \% / \mathrm{hr}$. requires the growth of $c .4 \times 10^{5} \mathrm{~h}$ - bacteria/hr. (Ryan, 1955a) and accordingly, in the presence of excess glucose, the availability of $c .5 \times 10^{-3} \mu \mathrm{g}$. of histidine during the interval. When this amount of histidine was added in the presence of $1300 \mathrm{u}$. penicillin $/ \mathrm{ml}$. no additional death was observed. Therefore, this amount of histidine, when distributed among the $c .2 \times 10^{7}$ bacteria present, did not induce enough growth metabolism to make them sensitive to penicillin. But, on the other hand, when the amount of histidine was added that would hypothetically be released in one day $\left(1 \cdot 25 \times 10^{-1} \mu \mathrm{g}\right.$.) a rapid exponential death was induced in the presence of penicillin. Similarly, when lots of $5 \times 10^{-3} \mu \mathrm{g}$. histidine were added every hr. for $24 \mathrm{hr}$. (total $1.2 \times 10^{-1} \mu \mathrm{g}$.) death resulted rapidly. Since the effect of adding histidine every hour was the same as adding the sum of it all at once, it is unlikely that continual addition, which is impossible to achieve experimentally, would have given a different result. This death continued exponentially for at least $150 \mathrm{hr}$., many days after the histidine had been added.

This fact suggested that the bacteria, killed while growing on the added histidine, themselves yielded further histidine. None the less, the process is complex, for the death-rate did not accelerate as the simple conception of a chain reaction would predict and whatever penicillin 'lysis' occurred did not remove bacteria as countable units (see Trucco \& Pardee, 1958) for the total cell count remained stable. During this time the penicillin remained active, for growth of the histidine-starved $h^{-}$cultures in penicillin ensued upon the addition of $28 \mathrm{u}$. penicillinase and $12 \mu \mathrm{g}$. histidine but not when histidine alone was added. Furthermore, in the stationary phase in the absence of penicillin (and during the previous growth) mutations occurred at characteristic rates and the $\mathrm{h}^{+}$mutants overgrew the cultures; in the presence of penicillin no adaptive overgrowths were observed.

It may be concluded that comparable amounts of histidine are not being released during the histidine-limited stationary phase. The presence of penicillin alone, even for more than $300 \mathrm{hr}$., did not result in increased death; although, if the rate of turnover were only $0.16 \% / \mathrm{hr} ., 1 \cdot 2 \times 13^{-1} \mu \mathrm{g}$. histidine 
should have been released. Therefore a turnover of $2 \% / \mathrm{hr}$. seems out of the question and the overwhelming majority of the mutations occurring during the stationary phase could not be due to cryptic growth. A reservation would have to be put on these conclusions only if there were a threshold concentration of histidine between $1 \times 10^{-3}$ and $2 \times 10^{-3} \mu \mathrm{g} /$ culture $\left(1 \times 10^{-3} \mu \mathrm{g}\right.$. being contributed by the hypothetical lysis in each case) at which penicillin could induce death.

\section{Mutation in the presence of penicillin}

If mutations to $\mathrm{h}^{+}$took place in the presence of penicillin the resulting mutants would be unable to reveal themselves by overgrowth. As soon as the $h^{+}$mutant began to grow its sensitivity to the penicillin present would lead to death. The $\mathrm{h}^{+}$mutants arising in a stationary phase can, however, be kept from growing. The method of choice is to employ $\mathrm{h}^{-}$lac- bacteria suspended in histidine-free medium where the only carbon source is lactose. Lac $^{-}$cells have enough residual $\beta$-galactosidase activity to allow good survival under these conditions but not enough to permit growth. The $\mathrm{h}^{+}$lac ${ }^{-}$mutations occurring among such $\mathrm{h}^{-}$lac- bacteria can be enumerated after a long period in the stationary phase by the addition of penicillinase and glucose. Among a large number of cultures of this sort the accumulation of $\mathrm{h}^{+}$mutants is expressed by a decrease in the fraction of cultures without mutants.

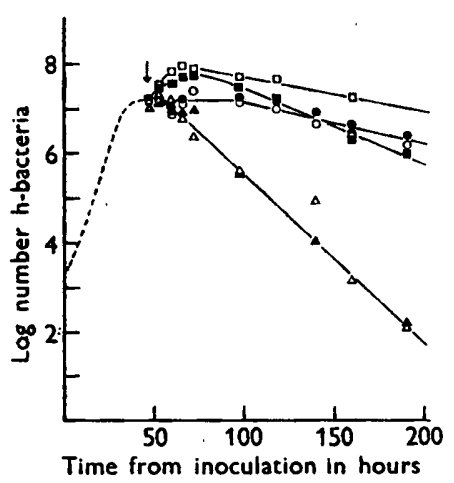

Fig. 7

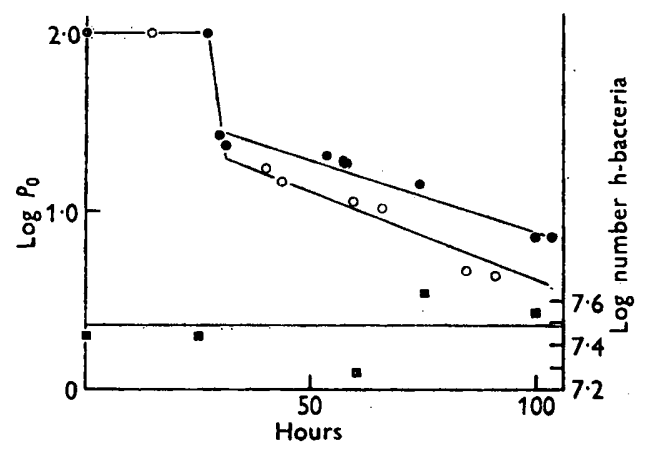

Fig. 8

Fig. 7. The effect of penicillin on the rate of death of $h^{-}$cultures starved for histidine. Penicillin and/or histidine were added at $48 \mathrm{hr}$. to cultures limited in growth by histidine exhaustion (see text for details). O, no addition;, $630 \mathrm{u}$. penicillin ; $\square, 0 \cdot 125 \mu \mathrm{g}$. histidine; $\Delta$, histidine $0 \cdot 125 \mu \mathrm{g}$. plus penicillin; $5,5 \times 10^{-3} \mu \mathrm{g}$. histidine added every $\mathrm{hr}$. for $24 \mathrm{hr}$; $\Delta, 630 \mathrm{u}$. penicillin and then $5 \times 10^{-3} \mu \mathrm{g}$. histidine every $\mathrm{hr}$. for $24 \mathrm{hr}$.

Tig. 8. The effect of penicillin on a histidine-limited stationary phase of $h$ - lac- bacteria. The ordinate on the left represents the log of the proportion (\%) of non-turbid cultures; the abscissa, the time from the addition to the cultures of supplements allowing overgrowth of the $h^{+}$mutants present. $O$, cultures which had ceased growth after $48 \mathrm{hr}$. because of the simultaneous exhaustion of limiting amounts of glucose and histidine and had been supplemented with excess glucose. $O$, similar cultures, supplemented at $48 \mathrm{hr}$. with lactose and penicillin instead of glucose; to which glucose and penicillinase were added $60 \mathrm{hr}$. later. $\square$, the number of viable $\mathrm{h}$ - bacteria (right ordinate) present at different times after penicillin and lactose were added to the experimental cultures. 
Several hundred $2 \mathrm{ml}$. cultures of $\mathrm{h}^{-}$lac- bacteria were grown to levèls of c. $3 \times 10^{7}$ cells/culture by the simultaneous exhaustion of histidine and glucose. After $48 \mathrm{hr}$., when growth was just finished on this limiting medium, sterilefiltered lactose and penicillin were added in $\mathbf{0 \cdot 1} \mathrm{ml}$. volumes sufficiently concen:trated to bring each culture to contain $0.05 \%(\mathrm{w} / \mathrm{v})$ lactose and $286 \mathrm{u}$. penicillin: Another group of cultures to which only lactose was added served as the control. Even after $278 \mathrm{hr}$. no adaptive overgrowths of $\mathrm{h}^{+}$mutants occurred in the control series but they were brought up on the addition of $1 \mu \mathrm{g}$. glucose/culture. Of course no adaptations occurred in the presence of penicillin until $40 \mathrm{u}$. penicillinase and $1 \mu \mathrm{g}$. glucose were added/culture. The penicillinase was free of histidine, as is shown by the fact that after its addition that $h^{-}$bacteria did not increase in number.

Among the mutants arising were those that had formed during the growth of the cultures and any that had occurred during the stationary phase. In order to determine the number of mutations that had occurred before the stationary phase, a third group of cultures received glucose at $48 \mathrm{hr}$., instead of lactose, sufficient to bring the concentration to $0.5 \%(w / v)$. In this control group any mutants present at the time of glucose addition could overgrow rapidly. As a result, the fraction of non-turbid cultures is abruptly reduced, as shown in Fig. 8. Thereafter as mutations continued to occur in the histidinelimited stationary phase a gradual reduction in the proportion of non-turbid cultures occurred at a constant rate. The point of intersection of the two slopes gives the $\boldsymbol{P}_{0}$ due to the presence of mutants arising during growth and from it the average number of mutations, $m$, was calculated as $1 \cdot 27$. This gives a mutation rate, $a$, during growth of $2 \times 10^{-8}$, while the rate/hr., $\mu$, during the ensuing stationary phase was $0.84 \times 10^{-9}$; both rates are usual for cultures with an excess of glucose.

In the series which had been in the presence of penicillin and lactose for $60 \mathrm{hr}$. and had then received penicillinase and glucose, the intersection of the two slopes was at a point equivalent to an $m$ of 1.63. Since, as Fig. 8 shows, no death occurred in penicillin, the difference between 1.63 and 1.27 or 0.36 (approximately the displacement between the two.curves) is the average number of mutations which occurred during the stationary phase in the presence of penicillin. The mutants developed in the stationary phase overgrew, along with those present when penicillin was added, as soon as glucose and penicillinase were introduced. This difference is statistically significant ( $P$ from $\chi^{2}=0.02$ ) and represents a rate of mutation, $\mu$, in the stationary phase of $1.3 \times 10^{-10}$. In a second experiment there was some death during $115 \mathrm{hr}$. exposure to penicillin $\left(k_{2}=10^{-2}\right)$ as well as in the cultures with lactose alone. The difference in $m$ of $\mathbf{0 . 2 8}$ was enlarged therefore by correction, assuming the $h^{+}$mutants died at the same rate as their $h^{-}$parents. The rate of mutation, $\mu$, calculated in this way, was $5.5 \times 10^{-10}$; the average rate of mutation in penicillin thus being $3.5 \times 10^{-10} /$ bacterium $/ \mathrm{hr}$. This is indistinguishable from the average rate of $1.9 \times 10^{-10}$ found among the control cultures to which only lactose had been added.

Inasmuch as this concentration of penicillin kills growing cells (Ryan, 
$1955 b$ ) no growth through cell turnover could have occurred; yet mutations occurred at a rate normal for lactose-suspended bacteria. Therefore the mutations observed took place in the absence of growth and cell division.

\section{Microscopic observation of starved cells}

Washed cultures of $\mathrm{h}^{-}$were spread on the surface of $\mathrm{H}^{-}$agar and their arrangement and form were observed through the high-dry objective of a microscope and drawn for reference. The plates were incubated at $37^{\circ}$ in a moist chamber and 2 days later the same fields were observed again. A total of 554. bacteria were studied in two experiments. Four bacteria seemed to have doubled; but the nature of bacterial division makes it impossible to be sure they: were not really double upon first observation. Five extra bacteria were seen on the second observation but they were invariably near structures on the agar. which might have concealed them in the first place. Seven cells were not observed at the second examination; these occurred in three groups of two and one singlet, and in each case they so resembled neighbours as to represent erroneous double registrations on the first observation. But even assuming that these 7 cells did lyse and completely disappear, the $1.3 \%$ they represent does not nearly approach the $31 \%$ that should have lysed to account for the mutations, which occur on agar as well as in liquid (Ryan, $1955 a$ ), on the turnover hypothesis. Nor were nearly enough doublings observed to replace such a large fraction of the population. It is concluded that for the most part these histidine-starved $h$ - bacteria neither lysed nor grew but were in a stationary phase in which they did not divide.

\section{DISCUSSION}

The hypothesis of cell-turnover in the stationary phase predicts that a fraction of the bacterial culture lyses every hour providing histidine which the surviving population may use for growth. Either the whole of the surviving population grows at a rate equal to the rate of lysis, or an equivalent fraction of the surviving population grows at a maximal rate, or something intermediate to these situations occurs. In any event, assuming the chance of mutation per generation to be the same as during unrestricted growth, the equivalent of the initial population would have been formed anew in $c: 50 \mathrm{hr}$. $\left(\mu=10^{-9}\right)$, having grown to replace lysed cells at a faster or slower rate. As a consequence, population shifts should have been detected in the mixtures of $\mathrm{lac}^{+}$and lac- bacteria; $\beta$-galactosidase should have increased and decreased in predicted ways and appeared in the culture fluid; penicillin should have killed the cultures and prevented mutation from occurring and the processes of lysis and replacement-growth: should have been seen on the surface of agar. None of these anticipated events was observed. Therefore, despite the reservations that have to be placed on each test of the hypothesis, it clearly does not stand the test of experiment. Markovich (personal communication) has independently, by other methods, come to the same mind about the same system. It must be concluded that the $\mathrm{h}$ - bacteria in this condition simply 
do not divide, or, if they do, in the face of the experiments reported, the rate of growth is not more than $10 \%$ of that required to account for the mutations observed.

Although there may be no appreciable cryptic growth of these stationary phase populations, there well may be duplication of genetic material. There does not appear to be any significant net increase in the content of polymers such as protein, RNA and DNA but a molecular turnover of one or more of these substances may occur within the non-dividing bacteria. Thus, there is still the possibility that experiments on this system by methods such as those utilized by Meselson \& Stahl (1958) will reveal that mutations arise as errors in gene replication. Indications that this may be the case can be had from the fact that the temperature relation of mutation during growth and in the stationary phase is the same (Ryan \& Kiritani, 1959). The involvement of metabolism with stationary phase mutation is seen in the facts that the rate of mutation from $\mathrm{h}^{-}$to $\mathrm{h}^{+}$in Escherichia coli growing at optimal rates is c. $4 \times 10^{-8} /$ bacterium/hour; in the stationary phase when metabolizable sugars are the carbon source (glucose, or lactose in the case of adapted $\mathrm{h}^{-} \mathrm{lac}^{+}$) the rate is $c .10^{-9}$, and where a poorly metabolizable sugar is the sole carbon source (lactose in the case of unadapted $\mathrm{h}^{-} \mathrm{lac}^{+}$or $\mathrm{h}^{-} \mathrm{lac}^{-}$) the rate is $c .10^{-10}$. In the absence of any added carbon source, or at $0^{\circ}$ whatever the carbon source, no mutations could be demonstrated in the stationary phase (see also Markovich, 1958). Wainwright (1956) found that the extent of preincubation of the spores of Streptomyces determined the rate at which they would mutate when stored in the cold, and Stubbe (1936) observed a sudden increase in the rate of mutation in stored seeds once they reached a certain age. The nondividing but still mutating cells of $\boldsymbol{E}$. coli are considered amenable to investigating questions involving the metabolic control of mutation and in deciding whether mutations are copy-errors (Ryan et al. 1959). They represent not only an ageing system, but also one resembling adult somatic cells inasmuch as cell division is at a minimum.

\section{REFERENCES}

Benzer, S. (1953). The induced synthesis of enzymes in bacteria analyzed at the cellular level. Biochim. biophys. Acta, 11, 383.

Conn, M. \& Torriani, A. M. (1953). The relationships in biosynthesis of the $\beta$-galactosidase- and $\mathrm{P}_{\mathrm{z}}$-proteins in Escherichia coli. Biochim. biophys. Acta, 10, 280.

MANDELSTAM, J. (1957). Turnover of protein in starved bacteria and its relationship to the induced synthesis of enzyme. Nature, Lond. 179, 1179.

MANDELSTAM, J. (1958). Turnover of protein in growing and non-growing populations of Escherichia coli. Biochem. J. 69, 110.

Markovich, 'H. (1958). Recherches sur Ia mutabilité spontanée de Escherichia coli. Proc. Xth int. Congr. Genetics, $2,179$.

Mrserson, M. \& Sraht, F. (1958): The replication of DNA in Escherichia coli. Proc. Nat. Acad. Sci., Wash. 44, 671.

Monod, J. (1949). The growth of bacterial cultures. Annu. Rev. Microbiol. 3, 371.

Novick, A. \& WiENer, M. (1957). Enzyme induction as an all-or-none phenomenon. Proc. Nat. Acad. Sci., Wash. 43, 553.

RYan, F. J. (1955a). Spontaneous mutation in non-dividing bacteria. Genetics; 40, 726. 
Ryan, F. J. (1955b). Phenotypic (phenomic) lag in bacteria. Amer. Nat. 89, 159.

Ryan, F. J. \& KrritainI, K. (1959). Effect of temperature on natural mutation in bacteria. J. gen. Microbiol. 20, 644.

Ryan, F. J., Rudner, R., Nagata, T. \& Kitani, Y. (1959). Bacterial mutation and the synthesis of macromolecules. Z. VererbLehre, 90, 148.

Ryan, F. J. \& Schneider, L. K. (1949a). Mutations during the growth of biochemical mutants of Escherichia coli. Genetics, 34, 72.

Ryan, F. J. \& Schneider, L. K. (1949b). The consequences of mutation during the growth of biochemical mutants of Escherichia coli. IV. The mechanism of inhibition of histidine independent bacteria by histidineless bacteria. $J$. Bact. 58, 201.

StubBe, H. (1936). Die Erhöhung der Genmutationsrate in alternden Gonen von Antirrhinum/majus L. Biol. Zbl. 56, 562.

Trucco, R. E. \& Pardee, A. B. (1958). Synthesis of Escherichia coli cell walls in the presence of penicillin. J. biol. Chem. 230, 435.

Wainwright, L. K. (1956). Spontaneous mutation in stored spores of a Streptomyces sp. J. gen. Microbiol. 14, 533.

(Received 14 April 1959) 